\title{
UPAYA MENINGKATKAN HASIL BELAJAR SISWA MATA PELAJARAN AKIDAH AKHLAK DENGAN MENGGUNAKAN MODEL PEMBELAJARAN BERBASIS NATURALISTIK EKSISTENSIAL SPIRITUAL
}

\author{
Dedi Wahyudi ${ }^{1}$, Nelly Agustin ${ }^{2}$ \\ podoluhur91@gmail.com ${ }^{1}$, ukhtinellyagustin@gmail.com ${ }^{2}$ \\ ${ }^{1,2}$ Institut Agama Islam Negeri Metro
}

\begin{abstract}
The purpose of this study was to find out based on the existential spiritual naturalistic learning model and student learning outcomes. This research is included in the type of research design literature. References obtained in the form of books, journals, articles, and other scientific works. The writing style used in this study is descriptive. This writing is done with an analytical approach and comparison between library sources that have been obtained. Using this naturalistic existential-based expression model can improve student learning outcomes. Both learning outcomes from aspects of cognitive (knowledge), affective aspects (morals) and psychomotrik aspects (skills / skills). The intelligence of students has the potential to improve learning outcomes. No exception on the subject Akidah Akhlak, which is in need of understanding and implementation of the contents of teaching materials. Such intelligence is naturalistic existential and spiritual. It is concluded that these three intelligences are dominantly average owned by the students. When associated with subjects of moral aqid and learning model, existential natural and spiritualistic intelligence is very relevant to teaching materials and learning frames. It appears that student learning outcomes are increasing with the use of this existential spiritualistic-based naturalistic learning model. Increased learning results seen from good morals and good students in accordance with existing norms. Also seen from the results of understanding through the evaluation of side.
\end{abstract}

Keywords: moral, learning model, naturalistic, existential, spiritual.

\begin{abstract}
Abstrak
Tujuan penelitian ini untuk mengetahui berdasarkan model pembelajaran naturalistik eksistensial spiritual dan hasil belajar siswa. Penelitian ini termasuk dalam jenis desain penelitian studi pustaka. Referensi yang didapatkan berupa buku, jurnal, artikel, maupun karya ilmiah lainnya. Gaya penulisan yang digunakan dalam penelitian ini yaitu secara deskriptif. Penulisan ini dilakukan dengan pendekatan analisis dan perbandingan antara sumber-sumber pustaka yang telah diperoleh. Dengan menggunakan model pembelajan berbasis naturalistik eksistensial spiritual ini dapat meningkatkan hasil belajar siswa. Baik hasil belajar dari aspek kognitif (pengetahuan), aspek afektif (akhlak) dan aspek psikomotrik (keterampilan/skill). Kecerdasan anak didik berpotensi untuk meningkatkan hasil belajar. Tidak terkecuali pada mata pelajaran Akidah Akhlak, yang sangat membutuhkan pemahaman dan implementasi dari isi bahan ajarnya. Kecerdasan tersebut adalah naturalistik eksistensial dan spiritual. Ditarik kesimpulan bahwa ketiga kecerdasan ini rata-rata dominan dimiliki oleh anak didik. Ketika dikaitkan dengan mata pelajaran akidah akhlak dan model pembelajaran, kecerdasan naturalistik eksistensial dan spiritual sangat relevan dengan materi ajar dan bingkai pembelajarannya. Terlihat bahwa hasil belajar siswa meningkat dengan penggunaan model pembelajaran berbasis naturalistik eksistensial spiritual ini. Hasil belajar yang meningkat terlihat dari akhlak anak didik yang baik dan benar sesuai dengan norma yang ada. Juga terlihat dari hasil pemahaman melalui evaluasi sisiwa.
\end{abstract}

Kata Kunci: akhlak, model pembelajaran, naturalistik, eksistensial, spiritual. 


\section{PENDAHULUAN}

Berkembangnya ilmu pengetahuan dan teknologi membawa manusia dalam persaingan global. Salah satu cara yang dapat ditempuh oleh suatu negara agar dapat bertahan dalam persaingan global yaitu dengan meningkatkan kualitas dan kuantitas sumber daya manusia (SDA) yang lebih baik. Pendidikan adalah salah satu cara untuk meningkatkan kualitas dan kuantitas sumber daya manusia menuju arah yang lebih baik. Kualitas SDA bangsa Indonesia telah tertulis dalam cita-cita bersama bangsadan selalu menjadi inti pokok tujuan pendidikan nasional. Tercantum dalam UU No. 2 tahun 1989 pasal 4, bahwa tujuan pendidikan nasional adalah cakap dalam segi kognitif (ilmu pengetahuan), segi afektif (nilai-nilai sosial dan keagamaan), dan segi psikomotorik (kesehatan dan keterampilan) (Muhammad Yaumi dan Sitti Fatimah S. Sirate, 2014). Sehingga diperlukan proses pembelajaran yang mencakup seluruh ranah tersebut. Proses pembelajaran yang dapat mencapai seluruh aspek dalam keberhasilan kegiatan belajar mengajar suatu bahan ajar di sekolah tertentu.

Proses pembelajaran adalah interaksi dan komunikasi proses pembelajaran yang terjadi antara guru dan siswa. Mulai dari awal hingga akhir dalam pembelajaran. Proses pembelajaran bisa dilakukan di dalam kelas, di lab, di lapangan terbuka, di luar kelas atau di alam terbuka. Semaksimal mungkin guru harus melibatkan siswa secara keseluruhan agar tercapainya tujuan pembelajaran. Tujuan dari suatu pembelajaran dapat dilihat dari evaluasi atau hasil belajar siswa dan guru. Jika guru telah profesional menjalankan perannya sebagai guru, maka keberhasilan dari suatu pembelajaran dapat dilihat dari hasil belajar siswa.

Hasil belajar siswa tidak hanya dilihat dari hasil ujian atau tes. Namun, hasil belajar siswa juga diperoleh dari hasil observasi perubahan tingkah laku pada siswa. Kemampuan yang dinilai dari hasil belajar ini adalah kemampuan kognitif dengan banyak menitik beratkan pada kemampuan berfikir, termasuk kemampuan menghafal, memahami, mengaplikasikan, menganalisis, menyintesis, dan kemampuan mengevaluasi pada siswa, serta kemampuan afektif (nilai-nilai) dan psikomotorik (skill atau kemampuan) siswa.

Evaluasi dapat diilustrasikan dengan timbangan, sedangkan hasil belajar siswa diilustrasikan dengan berat. Timbangan yang baik akan menghasilkan keakuratan/kevaliditasan berat yang baik pula. Timbangan yang buruk akan 
menghasilkan berat yang kurang valid atau tidak sesuai dengan kenyataan yang ada. Sehingga pada akhirnya fungsi-fungsi dari evaluasi tersebut tidak dapat terlaksana dengan baik atau malah salah dan berbuah fatal bagi masa depan siswa, karena hasil evaluasi yang diperoleh tidak sesuai dengan kemampuan dan pemahaman siswa.

Akidah akhlak adalah salah satu mata pelajaran di sekolah khususnya Madrasah Tsanawiyah, Madrasah Aliyah dan SLTA. Mata pelajaran akidah akhlak memiliki ciri khas tertentu dari mata pelajaran yang lainnya. Mata pelajaran akidah akhlak menitik beratkan pada ranah afektif. Sehingga siswa dapat mengetahui, memahami, merenungi, melihat dan mengaplikasikan mengenai pembelajaran akidah akhlak tersebut. Akidah akhlak merupakan mata pelajaran yang mengajarkan segi-segi kepercayaan (keimanan) dan tingkah laku (sikap) kepada anak didik. Akidah adalah suatu kepercayaan/keyakinan kepada Allah SWT., yaitu Islam. Akhlak adalah cerminan hati seseorang yang mengarahkan seseorang tersebut berbuat atau bertingkah laku atau bersikap dalam kehidupan sehari-hari. Akhlak seseorang juga cerminan dari akidah/kepercayaannya. Apabila akidah seseorang baik, maka baik pula akhlaknya (Kasmali, 2015).

Akhlak berasal dari bahasa Arab, jama'nya khuluqun, memiliki arti budi pekerti, amal, tingkahlaku atau tabiat. Kata khuluqun adalah kata yang berhubungan erat dengan kata khaliq (Pencipta) dan makhluk (yang diciptakan). Maka dikatakatakan bahwa akhlak adalah suatu pengertian yang timbul dari hasil komunikasi, hubungan khalik dengaan makhluk atau makhluk dengan makhluk (Masnun, 2015). Jadi, ada keterkaitan di sini mengenai pencipta dan yang diciptakan atau antara khalik dengan makhluk.

Pendidikan akidah akhlak merupakan salah satu cara menanamkan nilai-nilai kebaikan dan agama kepada anak didik, serta dapat menjadi karakter dari anak didik tersebut. Tujuan pendidikan akidah akhlak ini adalah agar anak didik dapat berkarakter baik menurut agama Islam, baik itu bersikap kepada Allah SWT., kepada diri sendiri, kepada orang lain dan kepada alam serta lingkungan, bahkan kepada bangsa dan tanah air (Sy, Hairunnisa, \& Rahmawati, 2014).

Akhlak seseorang terbagi menjadi dua macam, yaitu akhlak terpuji dan akhlak tercela. Akhlak terpuji adalah sikap dalam diri seseorang yang bersifat baik. Akhlak tercela yaitu sikap yang jelek pada diri seseorang (Kamal \& Abadi, 2016). Pembahasan mengenai akhlak terpuji dan tercela sangat banyak. Salah satu akhlak terpuji adalah rasa 
berpengharap kepada Allah SWT. atau raja'. Harapan atau raja' merupakan salah satu bagian dari akhlakul karimah yaitu berprasangka baik pada Allah SWT. Bukan sebaliknya, berputus asa dari rahmat dan karunia-Nya yang sangat besar. Berasanya rahmat dan karunia Allah meliputi alam dan seisinya, bahkan lebih luas dari itu semua.

Fakta yang terjadi dalam pendidikan di sekolah adalah siswa hanya mendapatkan materi dari guru setelah itu selesai. Siswa hanya mendengarkan dan kurang adanya timbal balik setelah selesai pembelajaran. Apalagi jika model pembelajaran yang guru gunakan hanya menitikberatkan pada guru bukan pada siswa. Sehingga pada akhirnya siswa hanya pasif dan kurang memahami dan mengaplikasikan materi ajar yang telah guru sampaikan. Oleh karena itu, dibutuhkan model pembelajaran yang dapat melibatkan intelektual, emosional, dan spiritual siswa dalam pembelajaran. Model pembelajaran yang mencakup aspek kognitif, afektif, dan psikomotorik.

Model pembelajaran pada hakikatnya adalah suatu bentuk pembelajaran yang tergambar dari awal sampai akhir proses pembelajaran. Model pembelajaran ini disajikan secara khas oleh guru masing-masing. Jadi, dapat dikatakan model pembelajaran merupakan bungkus atau bingkai dari suatu pembelajaran ("Pengertian Pendekatan, Strategi, Metode, Teknik, Taktik, dan Model Pembelajaran,” 2008). Model pembelajaran di dalam memiliki banyak isi, seperti pendekatan, strategi, metode, teknik dan taktik dalam suatu pembelajaran (Sutirman, 2013). Menyimpulkan dari pengertian di atas, model pembelajaran adalah pandangan umum dari suatu pembelajaran. Tercapai tidaknya pembelajaran dapat disimpulkan di model pembelajarannya.

Model pembelajaran yang dipilih dan dipersiapkan oleh guru tidak semata-mata karena guru mahir menggunakannya. Namun, pemilihan model pembelajarannya ini harus sesuai dengan kriteria pada anak didik dan tujuan pembelajaran yang harus dicapai pada proses pembelajaran tertentu. Model-model pembelajaran yang dipilih oleh guru hendaknya dapat mendorong anak didik untuk berpartisipasi dalam mengembangkan potensi belajarnya secara optimal (Aunurrahman, 2012). Salah satunya adalah model pembelajaran berdasarkan kecerdasan dan mata pelajaran.

Model pembelajaran adalah suatu bingkai dalam pembelajaran. Bingkai yang dipilih guru dalam menyampaikan materi di kelas guna mencapai tujuan pembelajaran (Sutirman, 2013). Model pembelajaran yang digunakan guru harus relevan dengan 
kecerdasan siswa. Melihat kenyataan yang ada kecerdasan siswa bermacam-macam dan tidak ada siswa yang memiliki kesamaan kecerdasan secara spesifik.

Kecerdasan seseorang memiliki banyak macam dan klasifikasi. Macam-macam kecerdasan seseorang tersebut tertuang dalam multiple intelligence. Multiple intelligence atau kecerdasan majemuk adalah suatu kemampuan yang dimiliki seseorang secara banyak atau lebih dari satu kebanyakan rata-rata pada seseorang untuk memahami dan memecahkan suatu masalah tertentu yang dihadapi dalam kehidupan (Thobroni \& Mustofa, 2012).

Kecerdasan majemuk ini bermula dari sebuah karya Howard Gardner dalam buku Frames Of Mind tahun 1983. Buku Frames Of Mind ini ditulis berdasarkan penelitian yang telah dilakukan selama beberapa tahun mengenai kemampuan kognitif pada manusia. Gardner menolak anggapan kebanyakan mengenai kecerdasan manusia yang hanya bersifat tunggal. Hal ini terbukti dengan hasil dari penelitian yang dilakukannya tersebut, bahwa kecerdasan manusia tidak tunggal atau hanya satu. Namun, majemuk atau banyak (multiple) (Thobroni \& Mustofa, 2012).

Menurut Howard Gardner Kecerdasan majemuk kecerdasan majemuk atau multiple intelligences menunjukkan macam-macam kecerdasan pada manusia. Kecerdasan seseorang tersebut meliputi kecerdasan verbal linguistic, kecerdasan logis matematis, kecerdasan visual spasial, kecerdasan musical, kecerdasan kinestetik, kecerdasan interpersonal, kecerdasan intrapersonal, kecerdasan naturalistik dan kecerdasan eksistensial (Machali, 2014). Setelah dilakukan analisis, pada mata pelajaran akidah akhlak jenis kecerdasan yang dominan dan model pembelajaran yang sesuai untuk digunakan adalah berbasis naturalistik eksistensial spiritual.

Kecerdasan naturalistik adalah kemampuan seseorang untuk mengetahui, memahami dan mempelajari alam, lingkungan dan makhluk hidup di sekitar dengan lebih dominan dan secara alamiyah (Muhammad Yaumi dan Sitti Fatimah S. Sirate, 2014). Hal ini ditekankan oleh (Amstrong, 2013) bahwa: "Kecerdasan naturalis adalah keahlian dalam mengenali dan mengklasifikasikan berbagai spesies flora dan fauna, dari sebuah lingkungan individu". Carvin dalam (Hambali, 2017) menyatakan bahwa kecerdasan naturalis adalah kemampuan seseorang untuk mengidentifikasi dan mengklasifikasi pola-pola alam (nature). 
Kecerdasan naturalistik adalah kemampuan untuk mengetahui, mengenali, membedakan, memahami dan mengungkapkan segala sesuatu yang ditemui di alam semesta. Kemampuan ini dilakukan seseorang dengan berusaha menyatukan hati dan pikirannya, serta perenungan secara mendalam mengenai objek yang dipahami (Anisa, 2010). Kecerdasan ini adalah suatu kemampuan seseorang yang menunjukkan kemahirannya dalam memahami, mengkalasifikasi, memahami dan menghayati flora dan fauna yang disekitarnya (Rocmah, 2016).

Salah satu contoh kecerdasan naturalis adalah anak merasa senang dan nyaman dengan alam, binatang dan makhluk hidup lainnya. Seperti menyentuh, memegang, mendekati, merasa sayang, bahkan memiliki rasa ingin memiliki makhluk hidup tersebut. Contoh spesifiknya adalah seseorang yang memiliki binatang peliharaan di rumahnya. Ketika menemukan hewan maka ia merasa senang, bahagia dan tertarik walaupun binatang tersebut kotor atau tidak lazim disukai oleh orang-orang. Naluri untuk memelihara sangat tajam, ingin rasanya memandikan atau bermain dengan hewan tersebut tanpa adanya rasa risih, takut atau jijik. Seseorang yang memiliki kecerdasan naturslistik sering sekali menganggap semua hewa adalah temannya, lucu, menggemaskan, butuh kasih sayang dan perlakuan yang baik bahkan special

Kecerdasan eksistensial adalah jenis kedominanan kecerdasan seseorang yang lebih menekankan pada diri seseorang yaitu berpikir. Seseorang akan cenderung lebih banyak berpikir mengenai dirinya dan proses yang telah ada/terjadi dan akan terjadi kedepannya (Wahyudi, 2011). Menurut Wilson dalam (Yaumi, 2013) Kecerdasan eksistensial adalah kemampuan untuk mengajukan pertanyaan-pertanyaan fundamental tentang eksistensi (keberadaan) atau pertanyaan tentang kerumitan suatu eksistensi.

Kecerdasan eksistensial merupakan kesadaran yang ada dan dapat berkembang pada diri seseorang melalui akal atau pikirannya. Peserta didik dengan kecerdasan eksistensial yang kuat memiliki ciri-ciri sebagai berikut: mencari bermakna belajar, cari koneksi di seluruh kurikulum, suka mensintesis ide-ide berdasarkan pembelajaran mereka, nikmati sastra dan adat istiadat dari budaya lain, memiliki hubungan yang kuat dengan keluarga dan teman-teman, mengembangkan identitas yang kuat dengan lingkungan mereka dan kota, dapat memiliki komitmen yang kuat untuk kesehatan dan kesejahteraan, cenderung melihat informasi relatif terhadap konteks yang disajikan (Wahyudi, 2011). 
Kecerdasan Eksistensial adalah kecerdasan yang mampu menyadari dan menghayati dengan benar dirinya dan tujuan hidup. Kecerdasan eksistensial banyak dijumpai pada para filosof. Dengan kecerdasan ini seseorang mampu untuk menjawab persoalan-persoalan terdalam atas eksistensi atau keberadaan manusia. Orang tidak puas hanya menerima keadaannya, keberadaannya secara otomatis, tetapi mencoba menyadarinya dan mencari jawaban yang terdalam (Kurniawan, 2015).

Kecerdasan spiritual banyak dijumpai dalam diri seseorang yang lebih dekat dan ingin mengenal Tuhan. Kecerdasan ini adalah kecerdasan yang menitik beratkan pada hati untuk memahami mengenai ke-Tuhan-an seperti agama, yaitu Islam dalam akidah akhlak (Thobroni \& Mustofa, 2012). Menurut Zohar dan Marshall Spiritual Intelligence adalah kemampuan yang berkenaan dengan internal seseorang, bawaan dari otak dan psikis manusia, melukiskan dasar yang paling dalam dari hati semesta alam dan seseorang (Sagala, 2009). Kecerdasan Spirtual seseorang diartikan sebagai kemampuan seseorang yang memiliki kecakapan transendden, kesadaran yang tinggi untuk menjalani kehidupan menggunakan sumber-sumber spiritual untuk memecahkan permasalahan hidup, dan berbudi luhur. Ia mampu berhubungan baik dengan tuhan, manusia, alam, dan diri sendiri (Siswanto, 2010).

Kecerdasan spiritual diyakini sebagai kecerdasan yang paling esensial dalam kehidupan manusia dibandingkan berbagai jenis kecerdasan lain. Kecerdasan spiritual itu bersandar pada hati dan terilhami sehingga jika seseorang memilki kecerdasan spiritual, maka segala sesuatu yang dilakukan akan berakhir dengan sesuatu yang menyenangkan, Zohar dan Marshall dalam (Hambali, 2017).

Contoh kecerdasan spiritual adalah selalu terpaut hati untuk selalu berada di tempat-tempat yang menentramkan jiwa (Hambali, 2017). Seperti masjid, tempattempat perenungan yang jarang dari keramaian (gunung, kamar, goa), majelis-majelis ilmu pengetahuan terutama agama (pengajian, kajian Al-Qur'an Hadis), persawahan, pedesaan dan lain sebagainya. Merasakan bahwa melalui sarana-sarana tersebut akan membuat betambahnya pengetahuan pada dirinya, baik pengetahuan dunia maupun akhirat.

Kecerdasan spiritual adalah kecerdasan berdasaran nilai-nilai hati yang paling dalam. Kecerdasan spiritual ini sangat cocok dan bermakna dengan agama seseorang, pada mata pelajaran akidah akhlak ini yaitu Islam (Suwan Dewi, Dantes, \& Mudjijono, 
2013). Dalam dunia kerja, kecerdasan spiritual memberi dampak positif pada pemberdayaan staf dan kepuasan kerja. Studi yang dilakukan oleh Mosaybian dan Araghizade dalam (Muhammad Yaumi dan Sitti Fatimah S. Sirate, 2014) tentang pengaruh kecerdasan spiritual terhadap pemberdayaan pegawai menunjukkan bahwa kecerdasan spiritual berdampak positif pada pemahaman pegawai tentang kompetensi, efektivitas kerja, dan kebermaknaan suatu pekerjaan. Penelitian oleh (Sundari, 2017), kecerdasan spiritual berpengaruh signifikan terhadap efikasi diri mahasiswa. Penelitian oleh (Nurdiansyah, 2016) bahwa Secara langsung kecerdasan spiritual berpengaruh positif yang signifikan terhadap hasil belajar matematika siswa.

Model pembelajaran berbasis naturalistik eksistensial spiritual ini sangat relevan dan sinkron dengan mata pelajaran akidah akhlak. Melihat hakikat pada mata pelajaran akidah akhlak yaitu mengajarkan mengenai agama secara alami dan ilmiyah kepada siswa. Mata pelajaran akidah akhlak dapat diajarkan melalui alam sekitar, perenungan, dan aplikasi akhlak serta ibadah. Akhirnya diharapkan dengan model pembelajaran ini dapat meningkatkan hasil belajar siswa dalam mata pelajaran akidah akhlak lebih baik lagi. Tidak hanya meningkatkan hasil belajar siswa beberapa pertemuan saja. Namun, secara berkesinambungan pada seluruh pertemuan pembelajaran mata pelajaran akidah akhlak khususnya.

Mata pelajaran akidah akhlak adalah mata pelajaran yang menekankan pada keagamaan/spiritual, nilai-nilai, pemikiran, dan mengenai alam semesta. Ketika dikaitkan dengan kecerdasan manusia, mata pelajaran akidah akhlak ini relevan dengan tiga multiple intelligence. Ketiga kecerdasan majemuk tersebut adalah kecerdasan naturalistik, eksistensial dan spiritual. Oleh karena itu model pembelajaran yang dikaji dalam penelitian ini adalah model pembelajaran berbasis naturalistik, eksistensial dan spiritual.

Mengambil pemahaman dari model pembelajaran berbasis naturalistik, eksistensial dan spiritual, bahwa model ini adalah model pembelajaran yang di dalamnya melibatkan anak didik untuk berpikir secara aktif, berperan secara maksimal dan mengaplikasikan pembelajaran yang telah guru sampaikan. Siswa merenungkan, berpikir dan mencoba untuk memahami ketika mengikuti proses pembelajaran. Setelah guru selesai memberikan pembelajaran anak didik dapat mengaplikasikan pembelajaran tersebut dalam kehidupan sehari-harinya. 
Model pembelajaran berbasis naturalistik, eksistensial dan spiritual dalam pelaksanaannya dapat menggunakan banyak macam metode. Namun dalam pembahasan ini peneliti menggunakan dua macam metode, yaitu metode karya wisata (tadabbur alam) dan metode perenungan.

Model pembelajaran berbasis naturalistik, eksistensial dan spiritual dalam metode karya wisata dilakukan dengan proses pembelajaran di luar kelas. Seperti belajar dan berlibur kesuatu tempat wisata, museum, dan lain sebagainya. Anak didik terjun langsung dalam praktek suasana pembelajaran, dengan demikian anak didik dapat merasakan dan memahami pembelajaran secara langsung dan nyata.

Salah satu contoh dari karya wisata adalah tadabbur alam, yaitu belajar di alam dan dari alam dengan memahaminya. Kegiatan belajar di alam dimulai dengan melihat, merasakan, memperhatikan, memikirkan, mengelompokkan, mengambil makna, memahaminya dan mengaplikasikannya dalam kehidupan sehari-hari (Hambali, 2017). Metode ini adalah sebagian dari cara siswa belajar secara mandiri atau tanpa paksaan. Siswa dengan inisistif sendiri belajar tanpa adanya paksaan atau bantuan dari pihak lain (Tahar, 2006). Kemudian Tadabbur Alam sendiri merupakan sarana pembelajaran untuk lebih mengenal ke Maha Besaran Allah SWT yang telah menciptakan langit dan bumi serta segala isinya (Hambali, 2017).

Model pembelajaran berbasis naturalistik, eksistensial dan spiritual dalam metode perenungan diimplementasikan dengan belajar di luar kelas atau pun di dalam kelas. Guru membuat susana pembelajaran menjadi sesuai dengan materi yang akan diajarkan. Sehingga siswa akan terbawa suasana nyata materi ajar dalam pembelajaran. Siswa akan mudah untuk memahami dan menyerap pembelajaran yang disampaikan guru.

Penelitian yang telah dilakukan berkaitan dengan berbasis kecerdasan majemuk pada manusia, diantaranya penelitian oleh (Widyasari, 2016) pembelajaran bahasa inggris dengan menggunakan metode multiple intelligences. Penelitian oleh (Saputra, 2010) mengenai kepemimpinan transformasional yang didukung dengan adanya kecerdasan emosi dan kecerdasan spiritual, diyakini akan dapat membawa organisasi meraih tujuannya dan menuju perubahan organisasi kearah yang lebih baik. Kecerdasan emosi dan kecerdasan spiritual sebagai faktor pendukung kepemimpinan transformasional dan perubahan organisasional. Kemudian penelitian oleh (Hambali, 2017) menguraikan secara subjektif dengan pendekatan deskriptif kualitatif konsep 
pembelajaran Tadabbur alam dalam meningkatkan kecerdasan naturalis dan kecerdasan spiritual siswa. Kemudian penelitian oleh (Muhammad Yaumi dan Sitti Fatimah S. Sirate, 2014) ini yaitu model pembelajaran berbasis kecerdasan spiritual untuk perbaikan karakter, dan mendeskripsi model perbaikan karakter melalui program pembelajaran berbasis kecerdasan spiritual. Penelitian oleh (Wahyudi, 2011) pembelajaran IPS berbasis kecerdasan intrapersonal, interpersonal dan eksistensial.

Penelitian lainnya yaitu relasi kecerdasan spiritual dan pencarian jejak Tuhan (Hudori, 2013), pengaruh kecerdasan intelektual, kecerdasan emosional dan kecerdasan spiritual pada kinerja alumni Fakultas Ekonomi Universitas Udaya (studi empiris mahasiswa MAKSI dan PPAk) (Pande, 2017), pengembangan kecerdasan naturalis anak di Sentra Bahan Alam pada Paud Terpadu Dharma Wanita Kota Jantho Kabupaten Aceh Besar (Yunisari \& Amri, 2016), determinasi kecerdasan spiritual dan pola asuh orang tua terhadap kecenderungan perilaku menyimpang siswa kelas X SMA Bhaktiyasa Singaraja (Suwan Dewi et al., 2013), pengaruh kecerdasan spiritual terhadap komitmen organisasi melalui kepuasan kerja sebagai variabel intervening (studi pada karyawan PT Calmic Indonesia Cabang Palembang) (Hazisma, 2013), dan pengaruh metode pembelajaran dan kecerdasan naturalis terhadap pengetahuan siswa tentang konsep ekosistem (eksperimen di Sekolah Dasar Negeri 4 Tangerang) (Husin, 2017), pengaruh pembelajaran berbasis masalah dan kecerdasan naturalis terhadap kemampuan siswa dalam memecahkan masalah lingkungan hidup (Suhirman, 2017), pembelajaran berbasis kegiatan pertanian dalam mengembangkan kecerdasan naturalistik (Retnosari, 2012), pengaruh kecerdasan intelektual, kecerdasan emosional dan kecerdasan spiritual terhadap sikap etis mahasiswa (Agustini \& Herawati, 2013), pengaruh kecerdasan intelektual, kecerdasan emosional, dan kecerdasan spiritual pada profesionalisme kerja auditor (Dharmawan, 2013).

Berdasarkan uraian penjelasan di atas dan penelitian terdahulu, keterbaharuan penelitian ini dalam jenis penelitian yang digunakan berupa studi pustaka. Jenis penelitian sebelumnya menggunakan kuantitatif maupun kualitatif. Tujuan penelitian ini untuk mengetahui berdasarkan model pembelajaran naturalistik eksistensial spiritual terhadap hasil belajar siswa. 


\section{METODOLOGI PENELITIAN}

Penelitian ini termasuk dalam jenis desain penelitian studi pustaka. Penelitian studi pustaka adalah penelitian yang bersumber hanya dari data sekunder. Data sekunder tersebut diperoleh dari referensi-referensi tertentu yang bersifat terbatas. Referensi yang didapatkan berupa buku, jurnal, artikel, maupun karya ilmiyah lainnya. Oleh karena tulisan ini dimaksudkan untuk penelitian studi pustaka, maka sumber-sumber yang diambil hanya memfokuskan pada kajuan pustaka semata.

Pengumpulan data dilakukan dengan cara mencari dan mengumpulkan sebanyakbanyaknya referensi pustaka guna mendapatkan kevalidan yang tepat (Septiani \& Rahmah, 2012). Gaya penulisan yang digunakan dalam penelitian ini yaitu secara deskriptif. Penulisan ini dilakukan dengan pendekatan analisis dan perbandingan antara sumber-sumber pustaka yang telah diperoleh. Analisis yang dilakukan adalah berdasarkan model pembelajaran naturalistik eksistensial spiritual dan hasil belajar siswa.

\section{HASIL KAJIAN DAN PEMBAHASAN}

Hasil kajian dan pembahasan dari penelitian yang berjudul Upaya Meningkatkan Hasil Belajar Siswa Mata Pelajaran Akidah Akhlak dengan Menggunakan Model Pembelajaran Berbasis Naturalistik Eksistensial Spiritual dari berbagai studi pustaka yang telah peneliti lakukan, dapat peneliti jelaskan adalah sebagai berikut:

Pertama, penelitian yang dilakukan oleh Hilmi Hambali, yaitu mengenai metode dalam kecerdasan naturalistik, yang tidak jauh beberda dengan model pembelajaran berbasis naturalistik eksistensial spiritual. Metode yang digunakan adalah karya wisata atau tadabur alam. Hasil penelitian menyebutkan bahwa siswa sangat meminati proses pembelajaran tersebut. Minat siswa pun terlihat melalui antusiasme siswa ketika mengikuti pembelajaran tersebut. Antusiasme siswa wajar terjadi karena metode tadabur alam/karya wisata ini sangat jarang dilakukan dalam proses pembelajaran. Biasanya pembelajaran karya wisata ini dilakukan satu kali dalam satu semester atau satu tahun (Hambali, 2017).

Pembelajaran dengan metode dan model ini sangat mempengaruhi motivasi belajar siswa. Siswa melihat dan mencoba untuk memahami alam, siswa akan lebih bertanggungjawab dan peduli dengan lingkungan alam sekitarnya. Siswa mengalami 
perkembangan penumbuhkan rasa kepekaan terhadap alam dan makhluk sekitarnya. Hal ini terbukti dengan ketertarikan siswa dengan kebersihan lingkungan. Terlihat siswa sangat mempedulikan dan memperhatikan kebersihan dan keserasian suasana lingkungan sekitarnya. Artinya akhlak (ranah afektif) siswa telah mengalami peningkatan ke arah yang lebih baik. Perbaikan sikap tersebut tercermin melalui rasa keterkaitannya anak didik dengan alam melalui keperdulian mereka dengan lingkungan.

Siswa mulai menghafal beberapa ayat Alqur'an dan hadis mengenai raja'. Semua ini adalah bukti bahwa pada diri anak didik mulai tumbuh rasa sikap raja'. Anak didik memiliki pengetahuan yang bertambah dengan model pembelajaran yang bersentuhan langsung dengan alam sehingga sikap raja' mudah muncul. Anak didik lebih dapat mengenal alam dan makhluk hidup sekitar secara nyata.

Hasil belajar anak didik yang berkaitan dengan ranah kognitif seperti menghafal mengalami peningkatan. Ketika anak didik terpaut dan terhubung langsung dengan alam sekitar maka akan lebih mudah baginya untuk mau dan menghafal ayat-ayat Al-Qur'an atau hadis yang bertemakan alam dan makhluk hidup, serta segala sesuatu yang berhubungan dengannya.

Melihat minat belajar dan motivasi belajar baik, serta peran siswa sangat aktif dalam proses pembelajaran, maka tidak dipungkiri bahwa hasil belajar siswa akan baik atau meningkat. Terbukti dengan antusiasme, kesenangan, kepekaan, kepedulian, kecintaan, keterkaitan siswa dengan alam dan maklhluk hidup dalam menjalani proses pembelajaran.

Kedua, penelitian yang ditulis oleh Putu Mahardika Pande mengenai Pengaruh Kecerdasan Intelektual, Kecerdasan Emosional dan Kecerdasan Spiritual pada Kinerja Alumni Fakultas Ekonomi Universitas Udaya (Studi Empiris Mahasiswa MAKSI dan PPAk). Hasil dari penelitian ini menunjukkan bahwa kecerdasan intelektual dan emosional berpengaruh pada kinerja alumni. Semakin tinggi kecerdasan emosional dan intelektual seseorang maka akan sangat berpengaruh terhadap kinerja seseorang. Kecerdasan spiritual tidak berpengaruh terhadap kinerja alumni, jadi semakin tinggi atau rendah kecerdasan spiritual seseorang maka kinerja dari seseorang tidak akan mengalami peningkatan atau penurunan kinerja (Pande, 2017). 
Hasil dari penelitian mengenai Pengaruh Kecerdasan Intelektual, Kecerdasan Emosional dan Kecerdasan Spiritual pada Kinerja Alumni Fakultas Ekonomi Universitas Udaya ini berbeda dengan penelitian-penelitian lain, yaitu mengenai hasil kecerdasan spiritual. Melihat kenyataan penelitian-penelitian lain kecerdasan spiritual sangat berpengaruh pada kehidupan seseorang tanpa terkecuali mengenai kinerja seseorang dalam kehidupan sehari-hari. Baik perkerjaan sebagai peran profesi, peran di rumah, dan peran dilingkungan sekitar.

Pada dasarnya suatu kecerdasan tidak dapat berdiri sendiri dan saling bekaitan satu sama lain. Maksudnya suatu kecerdasan ketika ingin diketahui hasil dari pemanfaatan atau penggunaannya tidak dapat dilihat secara sendiri-sendiri. Namun secara kerkolaborasi dengan kecerdasan lainnya. Sehingga didapatkan hasil yang benar dan konkret. Seperti dalam penelitian ini. Kecerdasan inelektual dan emosional berdampak sangat baik. Sedangkan ketika hanya melihat satu kecerdasan yakni kecerdasan spiritual maka tidak akan diperoleh hasil yang sesuai dan jelas. Maka dari itu kecerdasan spiritual ini harus digandengkan dengan kecerdasan lainnya agar tecapai hasil yang maksimal dalam pembelajaran.

Ekonomi atau muamalah dalam Islam sangat memerlukan kecerdasan spiritual, emosional dan intelektual. Bermuamalah harus dengan pemahaman, norma dan hukum Agama Islam, bersikap dan berperilaku juga harus sesuai dengan adab-adab dalam muamalah Islam. Seperti tidak diperbolehkan keliru, menipu, riba, mencurangi timbangan dan lain sebagainya. Muamalah dengan kecerdasan spiritual pada hakikatnya adalah guna menambah kedekatan kepada Allah SWT. dengan niat membantu sesama manusia, mengikuti sunnah Rasulullah saw. dan berharap ridha-Nya.

Ketika dalam hal ekonomi tidak membutuhkan kecerdasan spiritual, maka yang terjadi adalah bermuamalah hanya untuk mengumpulkan harta, memupuk riba dan mementingkan dunia. Hingga lupa bahwa manusia berusaha dan Allah yang memberi rezeki. Manusia akan kembali kepada Allah SWT. pada akhirnya manusia akan menjadi manusia yang kufur nikmat dan hanya bertujuan dunia tanpa adanya cita-cita untuk akhirat kelak.

Jadi, kecerdasan spiritual ini sangat mempengaruhi seseorang dalam belajar, tidak hanya hubungan dengan Allah saja. Namun juga hubungan dengan manusia lainnya. Seperti dalam hubungan ekonomi, sosial dan muamalah. Baik di rumah, lingkungan 
masyarakat maupun sekolah. Sehingga dapat menciptakan hubungan yang harmonis dan rukun sesama manusia.

Ketiga, penelitian yang ditulis oleh Azizah Husin. Hasil penelitian dari Pengaruh Metode Pembelajaran dan Kecerdasan Naturalis Terhadap Pengetahuan Siswa Tentang Konsep Ekosistem (Eksperimen di Sekolah Dasar Negeri 4 Tangerang) menunjukkan bahwa dengan adanya metode pembelajaran yang menitik beratkan pada kecerdasan naturalis akan membawa perilaku positif pada diri anak didik. Seseorang yang berinteraksi dengan alam tanpa memiki kecerdasan naturalis akan menimbulkan perilaku yang negatif pada alam. Seperti buang sampah sembarangan, merusak tumbuhan dan mengeksploitasinya (Husin, 2017).

Hasil belajar yang ideal adalah yang mencakup kemampuan siswa dalam hal pengetahuan, sikap dan keterampilan. Namun hasil belajar yang sangat diinginkan oleh kebanyakan guru dan orang tua adalah akhlak atau karakter bangsa yang baik (positif). Akhlak positif ini timbul dengan natural, terkadang siswa melakukan karena kesadarannya dan mencontoh guru ketika berinteraksi terutama dalam situasi di alam. Alam adalah suasana di mana siswa dapat mencurahkan hati nuraninya secara alami tapa adanya paksaan. Hal-hal positif cenderung terlihat dan terjadi di alam, karena keajaiban dan tabjub dengan alam yang sangat luar biasa indah serta nyamannya. Alam menumbuhkan nilai-nilai positif pada diri anak didik dan jauh dari hal-hal negatif. Siswa diharapkan dapat terpengaruh dengan nilai-nilai positif ini dan tidak sebaliknya.

Keempat, penelitian yang ditulis oleh Syukriyah Agustini dan Nyoman Trisna Herawati. Hasil penelitan tentang pengaruh kecerdasan spiritual terhadap sikap etis mahasiswa menunjukkan bahwa kecerdasan intelektual berpengaruh positif berkesinambungan terhadap sikap etis mahasiswa (Agustini \& Herawati, 2013). Ketika seorang guru menggunakan pembelajaran yang berbasis spiritual, maka hasil yang diperoleh adalah anak didik anak menanamkan nilai-nilai spiritual tersebut dalam kesehariannya. Baik ketika bersikap dan bertingkah laku yang baik seseuai dengan moral dan norma yang ada.

Guru adalah pemberi informasi dan teladan bagi siswa. Ketika guru menyampaikan informasi mengenai kejujuran, kedisiplinan dan kebaikan-kebaikan lainnya kemudian mengaplikasikannya. Secara natural dan spontan siswa akan mencerna informasi yang disampaikan guru tersebut. Siswa langsung dapat 
mengaplikasikan siakp-sikap tersebut dengan mencontoh ketauladannya gurunya. Logika atau akal anak didik berkerja, guru telah menyampaikan mengenai kebaikan dan melakukannya maka ia sebagai siswa harus mengikuti dan melakukan kebaikan itu juga. Karena kebaikan akan membawa manfaat dan kebahagiaan. Sebaliknya, keburukan membawa keburukan dan penderitaan.

Kelima, penelitian yang dilakukan oleh Nyoman Ari Surya Dharmawan. Hasil penelitiannya berungkap bahwa Kecerdasan spiritual adalah jenis kecerdasan yang membuat seseorang mampu menghadapi dan memecahkan persoalan hati dan jiwa, serta nilai dalam kesehariannya. Kecerdasan ini merpakan kemampuan seseorang yang dapat melihat nilai positif dari suatu hal yang tidak dapat dilihat dengan indera (Dharmawan, 2013). Ketika seorang siswa memiliki kedominanan dalam kecerdasan ini, maka seorang siswa tersebut akan mudah mengambil nilai positif dari permasalah yang ada dalam pembelajaran. Sehingga ia akan mendapatkan pengetahuan dan pemahaman mengenai pembelajaran dengan mudah, tepat, cepat dan benar.

Sebagai contoh siswa dapat secara langsung menyaksikan burung-burung, ikan, dan hewan lainnya mendapatkan rezeki dari Allah SWT dan mereka tidak mati karena kelaparan. Guru menceritakan hadis terkai dengan hal ini. Hingga siswa akan dengan mudah menangkap nilai positif dari cerita yang disampaikan guru dan dari apa yang telah siswa lihat secara langsung. Tanpa sadar nilai-nilai positif mengenai Allah Mahapemurah, pemberi rezeki, sesalu memelihara makhluknya dan Maha Kuasa tertanam dalam hati, jiwa dan pikiran siswa.

Keenam, penelitian yang ditulis oleh Suhairi Hazisma. Penelitian ini memperlihatkan bahwa kecerdasan spituritual berhubungan dengan kerja. Kerja tersebut dapat berupa melaksanakan proses pembelajaran dengan sukarela atau ikhlas dan tanpa paksaan. Sehingga pada akhirnya diperoleh kepuasan bekerja atau kepuasan dalam pembelajaran dengan hasil belajar yang memuaskan (Hazisma, 2013).

Anak didik yang dipaksa untuk belajar pada akhirnya akan menyebabkan kejenuhan tersendiri pada diri anak didik. Misalnya Senin sampai Jumat anak didik belajar (menghafal Al-Qur'an) dari pagi sampai malam tanpa istirahat dengan paksaan dari orang tuanya, kemudian hari Sabtu dan Minggu libur. Maka yang terjadi adalah anak didik meluapkan kejenuhan lima hari yang lalu pada hari Sabtu dan Minggu dengan hanya selalu bermain dan bersenang-senang. Ketika akan sampai pada hari 
Senin anak malas, tidak semangat dan tidak dapat belajar secara maksimal. Pikiran anak hanya berpusat pada datangnya hari Sabtu dan Minggu, pada hari itu ia dapat bahagia dan bermain tanpa adanya paksaan belajar yang menurutnya sangat melelahkan. Akhir yang didapatkan adalah hasil belajar anak yang kurang maksimal.

Berbeda dengan anak didik yang dihadirkan dengan model pembelajaran berbeda, model yang tidak biasa digunakan atau bahkan hanya digunakan pendidik satu kali dalam satu semester atau satu tahun. Pembelajaran yang tidak hanya berfokus pada belajar dan belajar, namun juga ada unsur hiburan dan interaksi dengan kecerdasankecerdasan yang ada pada diri anak, interaksi dengan teman dan lingkungan. Anak didik anak merasa tertarik tertantang, tergerak hati dan pemikirannya dengan naluri untuk belajar dengan senang, serius dan maksimal. Artinya anak didik belajar dengan suka rela tanpa paksaan. Akhirnya akan diperoleh hasil pembelajran yang maksimal dan memuaskan.

Ketujuh, penelitian yang dilakukan oleh Suhirman. Penelitian ini ditemukan bahwa siswa yang memilik kecerdasan naturalis lebih tinggi dapat memecahkan masalah pembelajaran dengan lebih mudah, cepat dan tepat dari pada siswa yang memiliki kecerdasan naturalis rendah (Suhirman, 2017). Permasalah yang diharapkan di sini adalah yang berkaitan dengan pembelajaran ataupun dengan kehidupan sehari-hari siswa. Pada akhirnya diperoleh hasil bahwa siswa dapat beradaptasi dengan pembelajaran dan kesehariannya dengan baik. Tanpa ada rasa bingung atas segala pembelajaran dan permasalah baru yang timbul dihadapan siswa tersebut.

Oleh karena itu, ketika dalam pembelajaran guru harus dapat memodifikasi model, metode dan strategi pembelajaran yang gunakannya secara maksimal. Sehingga dapat memunculkan kecerasan naturalis yang tinggi dan dominan. Berdampak pada kemampuan siswa dalam pembelajaran yang maksimal. Misalnya dengan mengaitkan siswa dengan hewan-hewan, tumbuan, tanaman bunga dan lingkungan alam sekitarnya.

Kedelapan, model pembelajaran berbasis naturalistik eksistensial spiritual dengan menggunakan media alam dapat meningkatkan kecerdasan belajar anak. Salah satunya adalah dengan memaksimalkan potensi kecerdasan naturalis yang ada dalam diri anak didik. Penelitian ini dilakukan oleh (Yunisari \& Amri, 2016), salah satu harapan dengan menggunakan model pembelajaran ini adalah untuk memaksimalkan dan memanfaatkan potensi kecerdasan yang ada pada anak didik. 
Potensi yang berada dalam diri anak didik berbeda-beda, artinya tidak sama. Salah satunya adalah potensi alami dengan kecerdasan naturalis. Anak yang berpotensi dengan kecerdasan ini dapat berprestasi dalam segi pertanian, perkebunan, perternakan, hewan-hewan peliharaan dan dokter hewan. Pemanfaatan kecerdasan yang maksimal akan berpengaruh pada hasil belajar dan potensisi siswa yang maksimal pula.

Kesembilan, diperoleh hasil penelitian yang menyimpulkan bahwa dengan kecerdasan spiritual yang dituangkan dalam model pembelajaran dapat membuat siswa berinteraksi baik dengan lingkungan sosial, personal dan dengan Sang Pencipta. Penelitian ini dilakukan oleh (Hudori, 2013) Melihat hasil penelitian ini siswa akan mudah untuk berinteraksi dengan diri sendiri, materi ajar yang berada di tempat yang berbeda-berbeda, lingkungan dan sosialnya.

Potensi yang dimiliki anak didik salah satunya adalah hubungan sosial. Hubungan yang baik antara seseorang dengan Tuhan-nya akan menghasilkan hubungan yang baik antara seseorang dengan sosialnya. Baik itu dirinya sendiri, keluarga, dan orang lain. Sosial yang baik ini akan membuat seseorang memiliki banyak teman, kepercayaan dan pengalaman yang akan menghantarkan pada pengetahuan, keterampilah dan akhlak yang baik juga. Begitu juga sebaliknya, ketika hubungan sosial buruk. Misal tidak memiliki teman, selalu bertengkar dan membuat kerusuhan hal ini akan berdampak pada sedikitnya akhlak dan pengetahuan pada seseorang. Pada akhirnya dalam proses belajar mengajar mengalami kesulitan dalam berinteraksi dengan guru apalagi dengan temanteman sekitar.

Kesepuluh, penelitian yang dilakukan oleh Gusti Agung Ari Suwan Dewi, hasil penelitian menunjukkan bahwa semakin tinggi kecerdasan spiritual seseorang maka akan mempengaruhi seseorang untuk tidak berbuat perilaku yang menyimpang (akhlak tercela). Begitupun sebaliknya, semakin rendah kecerdasan spiritual seseorang maka akan lebih mudah seseorang tersebut untuk melakukan perilaku menyimpang (Suwan Dewi et al., 2013).

Dihadirkan dampak positif dari penggunaan jenis model ini. Model yang akan banyak membentuk akhlak dan budi pekerti baik pada anak didik. Sehingga tidak perlu merasa khawatir lagi dengan krisis moral yang sekarang sedang melanda bangsa Indonesia. 
Ketika dihadirkan dengan alam dan fenomena alam yang ada. Misalnya fenomena grafitasi, oksigen dan organ tubuh manusia yaitu jantung. Guru menjelaskan kepada anak didik, yang menhadirkan oksigen dan gaya gravitasi adalah Allah. Ketika tidak ada gravitasi maka seisi bumi dan langit akan bertabrakan, jika tidak ada oksigen maka makhluk hidup tidak bisa bernafas dan hidup. Kemudian jantung adalah sentral dari kehidupan manusia, ketika jantung tidak lagi bertetak maka manusia telah dinyatakan meninggal. Seluruh keadaan tersebut adalah kuasa Allah yanag maha Besar lagi Maha Kuasa. Sehingga anak didik merenungkan dan bersyukur dengan banyaknya nikmat yang telah Allah berikan. Anak dapat mengaplikasikannya denga selalu menjaga bumi, lingkungan, dan dirinya dari hal-hal yang tidak baik.

Kesebelas, penelitian yang ditulis oleh Deddy Wahyudi mengenai Pembelajaran IPS Berbasis Kecerdasan Intrapersonal Interpersonal dan Eksistensial. Hasil dari penelitian ini membuktikan bahwa dengan menggunakan pembelajaran berbasis kecerdasan eksistensial dapat meningkatkan kualitas aktivitas belajar anak didik dan kualitas mengajar pendidik. Pada akhirnya peningkitan aktivitas ini dapat meningkatkan mutu dari suatu pendidikan dengan melihat evaluasi dari guru maupun siswa, dengan melihat hasil belajar anak didik (Wahyudi, 2011).

Model pembelajaran yang digunakan oleh guru mengacu pada kemampuan dan kecerdasan anak didik, maka akan lebih mengoptimalisasi potensi baik siswa. Kemampuan dan kecerdasan yang dituangkan dalam model pembelajaran bervariatif atau gabungan dari kemampuan dan kecerdasan yang ada pada anak didik. Sehingga keseluruhan anak didik akan maksimal dalam interaksi belajar mengajar. Pada akhirnya, akan diperoleh hasil belajar yang baik dan maksimal. Seperti, hasil evaluasi belajar dan akhlak pada anak didik, yaitu nilai dan anak didik akan cenderung untuk berakhlak baik serta terhindar dari akhlak buruk.

Berdasarkan hasil penelitian-penelitian di atas, dapat disimpulkan bahwa dengan penggunaan Model Pembelajaran berbasis Naturalistik Eksistensial Spiritual dapat diterapkan pada Mata Pelajaran Akidah Akhlak, materi raja' atau rasa berharap kepada Allah SWT.

Kelebihan dari model pembelajaran berbasis naturalistik eksistensial spiritual diantaranya yaitu: 
1. Menciptakan suasana dan kondisi belajar siswa menjadi lebih berbeda dan menarik;

2. Menimbulkan semangat dan motivasi belajar siswa yang lebih tinggi;

3. Membuat siswa lebih berpikir faktual dan alami;

4. Menumbuhkan kecintaan siswa dengan mata pelajaran atau bahan yang diajarkan guru;

5. Melatih siswa berinterakdi dengan alam dan makhluk hidup;

6. Melatih interaksi siswa dengan lingkungan dan teman-temannya;

7. Guru dan siswa-siswa lebih merasakan ikatan batin lebih kuat (kekeluargaan);

8. Meningkatkan kecerdasan naturalistik, eksistensial, dan spiritual siswa.

Sedangkan untuk kekurangan dari model pembelajaran berbasis naturalistik eksistensial spiritual adalah sebagai berikut:

1. Memakan waktu, biaya dan energi yang tidak sedikit dalam proses pembelajaran;

2. Membutuhkan persiapan yang tidak sedikit dan mantap;

3. Membutuhkan penjagaan yang lebih optimal karena belajar di alam atau di luar sekolah;

4. Menguras energi guru dan siswa karen optimalisasi belajra di lingkuran luar sekolah;

5. Perlu adanya persiapan yang maksimal oleh guru;

6. Biasanya model pembelajaran ini dilakukan oleh guru yang sudah berpengalaman;

7. Tidak semua mata pelajaran dapat menggunakan model ini, karena model ini berdasarkan pada lingkungan dan alam sekitar.

\section{SIMPULAN DAN SARAN}

Sampailah pada kesimpulan dari penjelasan upaya meningkatkan hasil belajar siswa mata pelajaran akidah akhlak dengan menggunakan model pembelajaran berbasis naturalistik eksistensial spiritual di atas. Pembelajaran akidah akhlak dengan menggunakan model ini dapat meningkatkan hasil belajar siswa. Hasil belajar siswa tersebut dapat berupa pemahaman mengenai ilmu pengetahuan, akhlak dalam kehidupan 
sehari-hari dan kemampuan siswa dalam dirinya yang membedakan siswa satu dengan lainnya.

Penerapan model pembelajaran berbasis naturalistik eksistensial spiritual ini membutuhkan pemahaman guru secara tepat dan benar, agar penerapannya dalam pembelajaran dapat berjalan dengan baik. Pada akhirnya dengan penggunaan model pembelajaran ini dapat meningkatkan hasil belajar siswa dan mencapai tujuan pembelajaran.

Jadi seorang guru dalam menggunakan model pembelajaran harus menyesuaikan dengan mata pelajaran yang akan diajarkan. Guru juga harus menyesuaikan model pembelajaran dengan kemampuannya, sarana, prasarana dan kemampuan sekolah serga kemampuan anak didik. Ketika semuanya relevan, maka akan dihasilkan hasil belajar/evaluasi yang diinginkan sesuai dengan tujuan pembelajaran. 


\section{DAFTAR PUSTAKA}

Agustini, S., \& Herawati, N. T. (2013). Pengaruh Kecerdasan Intelektual, Kecerdasan Emosional Dan Kecerdasan Spiritual Terhadap Sikap Etis Mahasiswa S1 Akuntansi Universitas Pendidikan Ganesha Singaraja. JIMAT (Jurnal Ilmiah Mahasiswa Akuntansi S1), 1(1).

Amstrong, T. (2013). Kecerdasan Multiple di Dalam Kelas. Jakarta: PT. Indeks.

Anisa, A. (2010). Aplikasi Paradigma Naturalistik Fenomenologi Dalam Penelitian Arsitektur. NALARs, 9(1).

Aunurrahman. (2012). Belajar dan Pembelajaran (6th ed.). Bandung: Alfabeta.

Dharmawan, N. A. S. (2013). Pengaruh Kecerdasan Intelektual, Kecerdasan Emosional, Dan Kecerdasan Spiritual Pada Profesionalisme Kerja Auditor. JINAH (Jurnal Ilmiah Akuntansi Dan Humanika), 2(2).

Hambali, H. (2017). Eksplorasi Pembelajaran Tadabbur Alam Dalam Meningkatkan Kecerdasan Naturalis (Naturalistik Intellegence) Dan Kecerdasan Spiritual (Spiritual Intellegence) Siswa SMP Unismuh Makassar. Jurnal Pendidikan Fisika, 5(1), 99-108.

Hazisma, L. S. (2013). Pengaruh Kecerdasan Spiritual terhadap Komitmen Organisasi Melalui Kepuasan Kerja Sebagai Variabel Intervening (Studi pada Karyawan PT Calmic Indonesia Cabang Palembang). ORASI BISNIS, 9(3).

Hudori, H. H. (2013). Relasi Kecerdasan Spiritual Dan Pencarian Jejak Tuhan. SOUL, $1(2)$.

Husin, A. (2017). Pengaruh Metode Pembelajaran Dan Kecerdasan Naturalis Terhadap Pengetahuan Siswa Tentang Konsep Ekosistem (Eksperimen di Sekolah Dasar Negeri 4 Tangerang). Jurnal Pendidikan Lingkungan Dan Pembangunan Berkelanjutan, 13(2), 53-65.

Kamal, M., \& Abadi, A. M. (2016). Pelaksanaan Pembelajaran Pendidikan Akidah Akhlak. Jurnal Tunas Bangsa, 1(1).

Kasmali, K. (2015). Sinergi Implementasi Antara Pendidikan Akidah Dan Akhlak Menurut Hamka. Jurnal THEOLOGIA, 26(2).

Kurniawan, A. (2015). Pembelajaran Dengan Kecerdasan Jamak di Sekolah. Al Ibtida: Jurnal Pendidikan Guru MI, 2(2), 1-18.

Machali, I. (2014). Dimensi Kecerdasan Majemuk Dalam Kurikulum 2013. Insania, $19(1), 21-45$.

Masnun, M. (2015). Implementasi Pendekatan Contextual Teaching And Learning Dalam Pembelajaran Akidah Akhlak Di Madrasah Ibtidaiyah. Al Ibtida: Jurnal Pendidikan Guru MI, 2(1). 
Muhammad Yaumi dan Sitti Fatimah S. Sirate. (2014). Kontruksi Model Pembelajaran Berbasis Kecerdasan Spiritual untuk Perbaikan Karakter, 20 Edisi Khusus.

Nurdiansyah, E. (2016). Pengaruh Kecerdasan Spiritual, Kecerdasan Emosional, Dampak Negatif Jejaring Sosial Dan Kemampuan Berpikir Divergen Terhadap Hasil Belajar Matematika Siswa. Journal of Educational Science and Technology (EST), 2(3), 171-184.

Pande, P. M. (2017). Pengaruh Kecerdasan Intelektual, Kecerdasan Emosional dan Kecerdasan Spiritual pada Kinerja Alumni Fakultas Ekonomi Universitas Udaya (Studi Empiris Mahasiswa MAKSI dan PPAk).

Pengertian Pendekatan, Strategi, Metode, Teknik, Taktik, dan Model Pembelajaran. (2008).

Retnosari, P. (2012). Pembelajaran Berbasis Kegiatan Pertanian Dalam Mengembangkan Kecerdasan Naturalistik. Jurnal Pendidikan Anak Usia Dini, $6(2)$.

Rocmah, L. I. (2016). Peningkatan Kecerdasan Naturalis Melalui Bermain Messy Play terhadap Anak Usia 5-6 Tahun. PEDAGOGIA: Jurnal Pendidikan, 5(1), 47-56.

Sagala, S. (2009). Konsep dan Makna Pembelajaranuntuk Membantu Memecahkan Problematika Belajar dan Mengajar. (7th ed.). Bandung: Alfabeta.

Saputra, M. H. (2010). Kecerdasan Emosi dan Kecerdasan Spiritual Sebagai Faktor Pendukung Kepemimpinan Transformasional dan Perubahan Organisasional. SEGMEN-Manajemen, 1, 17-32.

Septiani, S. T., \& Rahmah, E. (2012). Peningkatan Kualitas Layanan Konten Jurnal Melalui Rebranding (Studi Kasus di Perpustakaan Universitas Andalas). Ilmu Informasi Perpustakaan Dan Kearsipan, 1(1), 49-57.

Siswanto, W. (2010). Membentuk Kecerdasan Spiritual Anak. Jakarta: Amza.

Suhirman. (2017). Pengaruh Pembelajaran Berbasis Masalah Dan Kecerdasan Naturalis Terhadap Kemampuan Siswa Dalam Memecahkan Masalah Lingkungan Hidup (Studi Eksperimen Di SMPN 1 Mataram NTB). Jurnal Pendidikan Lingkungan Dan Pembangunan Berkelanjutan, 13(1), 1-15.

Sundari. (2017). Pengaruh Kreativitas dan Kecerdasan Spiritual Terhadap Efikasi Diri dan Kemandirian Mahasiswa Jurusan Manajemen Fakultas Ekonomi Universitas Islam Majapahit (UNIM) Mojokerto. Jurnal Ekonomi Pendidikan Dan Kewirausahaan, 3(1), 61-75.

Sutirman. (2013). Media dan Model-Model Pembelajaran Inovatif. Yogyakarta: Graha Ilmu.

Suwan Dewi, G. A. A., Dantes, N. D., \& Mudjijono. (2013). Determinasi Kecerdasan Spiritual Dan Pola Asuh Orang Tua Terhadap Kecenderungan Perilaku 
Menyimpang Siswa Kelas X Sma Bhaktiyasa Singaraja. Jurnal Ilmiah Bimbingan Konseling, 1(1).

Sy, S., Hairunnisa, H., \& Rahmawati, L. (2014). Pembelajaran Akidah Akhlak di Madrasah Tsanawiyah Negeri Model Darussalam Martapura Kabupaten Banjar. Tashwir, Jurnal Penelitian Agama Dan Sosial Budaya, 1(2).

Tahar, I. (2006). Hubungan kemandirian belajar dan hasil belajar pada pendidikan jarak jauh. Jurnal Pendidikan Dan Jarak Jauh, 7(2), 91-101.

Thobroni, M., \& Mustofa, A. (2012). Belajar dan Pembelajaran, Pengembangan Wacana dan Praktik Pembelajaran dalam Pembangunan Nasional (2nd ed.). Jogjakarta: Ap-Ruzz Media.

Wahyudi, D. (2011). Pembelajaran IPS Berbasis Kecerdasan Intrapersonal Interpersonal dan Eksistensial. Journal Pendidikan, Edisi Khus(1).

Widyasari, F. E. (2016). Pembelajaran Bahasa Inggris Dengan Menggunakan Metode Multiple Intelligences: Studi Kasus di Sekolah Internasional. Jurnal Pendidikan Edutama, 3(1), 31-46.

Yaumi, M. (2013). Pembelajaran Berbasis Kecerdasan Jamak (Multiple Intelligences: Mengidentifikasi dan Mengembangkan Multitalenta Anak. Jakarta: Kencana Prenada Media Group.

Yunisari, D., \& Amri, A. (2016). Pengembangan Kecerdasan Naturalis Anak Di Sentra Bahan Alam Pada Paud Terpadu Dharma Wanita Kota Jantho Kabupaten Aceh Besar. Jurnal Ilmiah Mahasiswa Pendidikan Anak Usia Dini, 1(1). 